\title{
Erratum
}

\section{Lorenz Oken (1779-1851): Naturphilosophie and the reform of natural history - ERRATUM}

\section{ANDREA GAMBAROTTO}

https://doi.org/10.1017/S0007087417000310, published by Cambridge University Press, 18 May 2017.

Corrections to Andrea Gambarotto, 'Lorenz Oken (1779-1851): Naturphilosophie and the reform of natural history', British Journal for the History of Science (2017) 50:2:

1. Footnote 3 should read, "Nicholas Jardine, 'Naturphilosophie and the kingdoms of nature', in Nicholas Jardine, Jim Secord and Emma Spary (eds.), Cultures of Natural History, Cambridge: Cambridge University Press, 1996, p. 232.”

2. Footnote 8 should read, "Immanuel Kant, Kritik der Reinen Vernunft 2: Auflage 1787, Akademie Ausgabe, Band III, Berlin: Königlich Preußische Akademie der Wissenschaften, 1968, p. 691, as translated in Critique of the Power of Judgment, eng. tr. by P. Guyer \& E. Matthews, Cambridge: Cambridge University Press, 2000, emphasis added.”

\section{Reference}

Andrea Gambarotto, 'Lorenz Oken (1779-1851): Naturphilosophie and the reform of natural history', BJHS (2017) 50(2), pp. 329-340. doi:10.1017/S0007087417000310. 